\title{
Clinical evidence of the relationship between aspirin and breast cancer risk (Review)
}

\author{
NADIA J. JACOBO-HERRERA ${ }^{1}$, CARLOS PÉREZ-PLASENCIA ${ }^{2,3}$, ELIZABETH CAMACHO-ZAVALA ${ }^{1}$, \\ GABRIELA FIGUEROA GONZÁLEZ ${ }^{2}$, EDUARDO LÓPEZ URRUTIA ${ }^{3}$, \\ VERÓNICA GARCÍA-CASTILLO ${ }^{2}$ and ALEJANDRO ZENTELLA-DEHESA ${ }^{1,4}$ \\ ${ }^{1}$ Unidad de Bioquímica, Instituto Nacional de Ciencias Médicas y Nutrición 'Salvador Zubirán', \\ Tlalpan 14000, Mexico, D.F.; ${ }^{2}$ Unidad de Biomedicina FES-Iztacala, Universidad Nacional Autónoma de \\ México UNAM, Tlalnepantla 54090; ${ }^{3}$ Laboratorio de Oncogenómica, Instituto Nacional de Cancerología, \\ Tlalpan 14080, Mexico, D.F.; ${ }^{4}$ Medicina Genómica y Toxicología Ambiental, Instituto de Investigaciones \\ Biomédicas, UNAM, Tercer Circuito Exterior Ciudad Universitaria, Mexico, D.F., Mexico
}

Received March 21, 2014; Accepted May 15, 2014

DOI: 10.3892/or.2014.3270

\begin{abstract}
In the search for new therapeutic alternatives against cancer, either as a preventive treatment or for advanced stages, it is common to appeal to well-known drugs used for the treatment of other diseases that may interfere with the metabolic pathways involved in carcinogenesis. Non-steroidal anti-inflammatory drugs (NSAIDs) display anticancer activity through the inhibition of the COX-2 enzyme, triggering processes such as apoptosis, a reduction in proliferation and inhibition of carcinogenesis. Breast cancer is a neoplasm with the highest incidence and mortality rate among young women worldwide. Epidemiologic data have shown that drugs such as NSAIDs, particularly aspirin, reduce the relative risk of breast cancer. However, in the subgroup of responsive patients, dose, time and frequency of use have not yet been established. Here, we review the reports published during the last 10 years regarding the relationship between breast cancer and aspirin.
\end{abstract}

\section{Contents}

1. Introduction

2. Epidemiologic studies

3. Aspirin as an inhibitor of metastasis

4. Aspirin, mechanisms of action

5. Conclusions

Correspondence to: Dr Nadia J. Jacobo-Herrera, Unidad de Bioquímica, Instituto Nacional de Ciencias Médicas y Nutrición ‘Salvador Zubirán', Vasco de Quiroga 15, Tlalpan 14000, Mexico, D.F., Mexico

E-mail: nadia.jacobo@gmail.com

Key words: breast cancer, aspirin, NSAIDs, chemoprevention, metastasis, COX-2, inflammation

\section{Introduction}

Worldwide, breast cancer (BC) is the leading cause of death in women due to malignant neoplasms. In Mexico, the incidence of this disease reported in 2008 was 13,939 new cases per 100,000 inhabitants (1). In two decades (1990-2010), the annual risk increased from 2 to $5 \%$, being more frequent in the north and central part of the country (2). In 2010, the National Institute of Statistics, Geography and Informatics of Mexico (INEGI) reported that 19 of every 100 women enrolled into a medical service, presented with a mammary neoplasm, and $47 \%$ of BC deaths were in women with ages ranging from 45 to 64 (3). There are many risk factors for the development of breast cancer. For the Mexican population, the principal risk factors include reproductive factors (e.g. age at menarche and menopause, nulliparity or late pregnancy and non-breastfeeding women) and genetics (BRCA1 and BRCA2 genes) (3). In contrast, a diet rich in fruits and vegetables, low alcohol consumption and no smoking habit, significantly reduce the probability to develop this disease (2).

The treatment for BC in the primary stages (I and II) generally consists of surgical procedures, followed by chemotherapy (mainly anthracycline-type drugs) and/or radiotherapy (depending on the stage of the cancer), offering successful and even curative results in the majority of cases (4). Notwithstanding, the cardiotoxicity of anthracyclines is well documented; the secondary effects are mainly cardiomyopathy and cardiac syncope (5). Epidemiologic studies indicate that $50 \%$ of patients exposed to anthracyclines develop cardiac abnormalities after 10 to 20 years of chemotherapy; $40 \%$ of patients present with arrhythmia and 5\% with heart failure (6). In addition, patients in advanced stages or with metastasis present a survival rate of $22 \%$ after 10 years of treatment (7).

In search for new alternatives to the conventional treatment and/or for the improvement of known therapies, aspirin has been one of the most attractive prevention strategy proposals. There is a long literature record, of over 20 years, concerning the study of aspirin and its effect on BC risk. An example of this 
is the meta-analysis performed by Khuder and Mutgi (2001), where evidence gathered from 1980 to 2000 was analyzed (8). In this work, the results highlighted that women with estrogen receptor (ER)-positive $\left(\mathrm{ER}^{+}\right)$tumors and who regularly consumed non-steroidal anti-inflammatory drugs (NSAIDs), presented a $22 \%$ reduction in BC risk [relative risk (RR) of $0.82 ; 95 \%$ confidence interval $(\mathrm{CI}), 0.75,0.89]$. In the case of cohort studies, they reported an RR of 0.78 (95\% CI, 0.62-0.99), and for case-control studies an RR of 0.87 (95\% CI, 0.84-0.91).

More recently, Agrawal and Fentiman (2008) reported that the use of NSAIDs decreased the risk of developing BC by $20 \%$ (9). The authors proposed that NSAIDs could be employed as coadjuvant or palliative treatment, together with hormonal therapies, in women diagnosed with BC. Nevertheless, a consensus regarding the ideal drug, the dosage, and administration time has not been reached.

Due to the controversial use of NSAIDs, particularly aspirin, and the risk of developing $\mathrm{BC}$, in this review we carried out a descriptive revision of the free access epidemiologic studies from 2000 to 2012 listed in PubMed, using the following search key words: 'aspirin or acetylsalicylic acid and breast cancer', 'non-steroidal anti-inflammatory drugs', 'clinical studies' and 'epidemiological reports'. The main objective of this article was to analyze whether aspirin reduces the risk of $\mathrm{BC}$ in women, and the optimal conditions required to benefit from the use of this drug. In order to organize the article, it was divided into three main sections: i) epidemiologic studies, ii) aspirin as an inhibitor of metastasis and iii) aspirin, mechanism of action. Table I summarizes the articles consulted in this review.

\section{Epidemiologic studies}

In this section, 20 studies are reviewed, 12 of them are cohort studies and the rest correspond to case-control studies. Both categories comprise studies in which $\mathrm{BC}$ was assessed exclusively and cancer studies where BC information was included. These works are presented in a chronological fashion, from 2000 to 2012.

Cohort studies. Johnson and colleagues (2002) (10) carried out a cohort study in the US in order to evaluate the effect of aspirin (and/or drugs with aspirin in their formulation), NSAIDs, or drugs used in the treatment of arthritis, in a population of 27,616 postmenopausal women. Less than $4 \%$ of the women were diagnosed with $\mathrm{BC}(\mathrm{RR}=0.80)$ after 6 years of monitoring. In the aspirin group, the multivariate-adjusted $\mathrm{RR}$ for BC was 0.71 (95\% CI, 0.58-0.87), considering those women that consumed aspirin at least 6 times a week and independent of the BC stage. In comparison, for the rest of the NSAIDs under the same conditions, the adjusted RR value was 1.01 (95\% CI, 0.83-1.25). One year afterwards, the Women Health Initiative (WHI) completed a study including 80,741 postmenopausal women (50-79 years of age) during 10 years (11). During this period, less than $2 \%$ of the participants were diagnosed with BC. Their results showed that the regular use of NSAIDs (for more than 5 years but less than 10 years), taking two or more tablets per week (doses over $100 \mathrm{mg}$, no further specification was given) reduced the incidence of $\mathrm{BC}$ by $21 \%$ ( $R R=0.79 ; 95 \%$ CI, 0.60-1.04). An increment of 7 percentage units was found in those women that had consumed NSAIDs for over 10 years $(\mathrm{RR}=0.72 ; 95 \% \mathrm{CI}, 0.56-0.91)$. Aspirin reduced by $21 \%$ the risk of $\mathrm{BC}$ at doses higher than $100 \mathrm{mg} /$ day; in comparison, ibuprofen was more effective diminishing the risk by $49 \%$. Importantly, they found that NSAIDs had a major impact in women with characteristics such as high mass index, lack of exercise, late pregnancy, family history of BC and/or hormonal therapy. The authors did not mention whether the cancer cases were diagnosed in situ or whether they were invasive.

In another study carried out in the US, researchers found a protective effect of aspirin against cancer, decreasing mortality rates in both genders (12). The databases consulted were from the First and Second National Health and Nutrition Examination Study (NHANES I and II; 1971-1975 and 19761980, respectively) (12). However, the level of protection depended on the type of neoplasia, gender and patient age. The results showed a reduction in the mortality rate in men and women that were aspirin users $(\mathrm{RR}=0.88,95 \% \mathrm{CI}, 0.85-0.99)$. For women with breast and ovarian cancer, they found reduced mortality in those patients that used aspirin $(\mathrm{RR}=0.82,95 \% \mathrm{CI}$, $0.49-1.36)$. In men, the use of aspirin reduced mortality by lung cancer $(R R=0.69,95 \%$ CI, 0.49-0.96). Nevertheless, they observed that when aspirin was ingested daily for a period longer than 5 years, the risk to develop bladder and central nervous system cancer was increased.

In California, US, an evaluation of BC risk and the use of NSAIDs was carried out in a population of 114,640 educators (13). Data were obtained from the California Teachers Study Cohort at baseline from 1995 to 1996, in a region with a high prevalence of $\mathrm{BC}$ (13). At the beginning of the poll, the participants were free of cancer. Six years later, 2,391 women were diagnosed with $\mathrm{BC}$ and were classified into two different groups: i) localized BC and ii) non-localized BC, including hormonal receptor-positive and -negative cancer. The tested drugs were aspirin, ibuprofen and acetaminophen. The last drug was included for comparative purposes, even though it is prescribed for pain relief. As a result of this cohort study, the researchers found no association in $\mathrm{BC}$ risk between daily and no regular use of aspirin and ibuprofen in combination with aspirin $(\mathrm{RR}=1.09,95 \% \mathrm{CI}=0.97-1.21$ for NSAIDs; and $\mathrm{RR}=0.98,95 \% \mathrm{CI}=0.86-1.13$ for aspirin); similar results to those previously reported for aspirin in 1996 (14). Concerning the hormone receptor groups, no statistically significant difference was observed for those patients with $\mathrm{ER}^{+} /$progesterone receptor $(\mathrm{PR})^{+}$breast cancer that were long-term aspirin users $(\mathrm{RR}=0.80,95 \% \mathrm{CI}, 0.62-1.03)$. Meanwhile, in the $\mathrm{ER}^{-} /$ $\mathrm{PR}^{-} \mathrm{BC}$ group, the daily use of aspirin for longer than 5 years increased the risk of $\mathrm{BC}(\mathrm{RR}=1.81,95 \% \mathrm{CI}=1.12-2.92)$. The same result was presented for patients with long-term daily use of ibuprofen; it was associated with an increased risk of BC ( $R R=1.51,95 \% \mathrm{CI}=1.17-1.95)$. Nevertheless, the authors could not validate their results, arguing that it could be a casualty.

Regarding the hormone receptor status, Kirsh and colleagues evaluated the effect of NSAIDs and aspirin, considering breast cancer risk according to $\mathrm{ER}^{+}$or $\mathrm{ER}^{-}$status, $\mathrm{PR}^{+}$or $\mathrm{PR}^{-}$status, smoking habit and arthritis, in women with incident $\mathrm{BC}$ (controls were randomly selected women) (15). The principal inclusion criteria for all participants were the daily use of drugs (for at least 2 months), as well as a dose of $325 \mathrm{mg}$ for 
the majority of aspirin users (78\% of users). Users of NSAIDs presented a reduced risk of $\mathrm{BC}(\mathrm{OR}, 0.76 ; 95 \% \mathrm{CI}, 0.66-0.88)$; similar for $\mathrm{ER}^{+} / \mathrm{PR}^{+}(\mathrm{OR}, 0.71 ; 95 \% \mathrm{CI}, 0.60-0.84)$ and for ER$^{-} / \mathrm{PR}^{-}$(OR, 0.80; 95\% CI, 0.62-1.03). The authors concluded that NSAIDs are more effective for diminishing the $\mathrm{BC}$ risk when they are consumed for more than 7 years, regardless of whether the drug contains acetylsalicylic acid or not.

Terry and colleagues (2004) evaluated patients with hormone receptor-positive or -negative BC tumors who used NSAIDs and the risk of cancer vs. a control population free of disease; no age restriction was considered in this study (16). The research group found that consuming aspirin once a week for at least 6 months corresponded to an inverse association with $\mathrm{BC}$ risk $(\mathrm{OR}=0.80,95 \% \mathrm{CI}, 0.66-0.97)$ with respect to never-users. On the other hand, for ibuprofen users under the same conditions, no association with $\mathrm{BC}$ risk vs. never-users was found $(\mathrm{OR}=0.91,95 \% \mathrm{CI}, 0.71-1.16)$. Not surprisingly, acetaminophen was not associated with $\mathrm{BC}$ risk $(\mathrm{OR}=1.02$, 95\% CI 0.80-1.31; users vs. never-users). However, a reduction in risk was observed for users of aspirin with hormone receptor-positive $\mathrm{BC}$ tumors $(\mathrm{OR}=0.74,95 \% \mathrm{CI}, 0.60-0.93)$, vs. patients with hormone receptor-negative tumors $(\mathrm{OR}=0.97$, 95\% CI, 0.67-1.40). Aspirin decreased the BC risk, particularly in postmenopausal women for each experimental subgroup studied $\left(\mathrm{ER}^{+} / \mathrm{PR}^{+}, \mathrm{ER}^{+} / \mathrm{PR}^{-}, \mathrm{ER}^{-} / \mathrm{PR}^{+}\right)$, except in patients with tumors negative for ER and PR, thus suggesting that it could have a chemopreventive effect in specific BC subtypes. One year afterwards, the same research group published an update of the aforementioned investigation, including 444 new cases, for a total of 7,006 patients with BC (17). The authors continued their investigation regarding the association between the regular use of NSAIDs and the risk of BC depending on hormone receptor status of the tumor. Their findings showed that the long-term use of NSAIDs diminished the risk of $\mathrm{BC}$, independent of the drug and the hormone receptor status of the tumor $(\mathrm{OR}=0.78,95 \% \mathrm{CI}, 0.63-0.97$ for regular use of NSAIDs; OR=0.86 for aspirin and $\mathrm{OR}=0.85$ for ibuprofen).

A cohort study in Denmark with 29,470 individuals, compared cancer incidence after exposure to aspirin at three concentrations $(75,100$ and $150 \mathrm{mg})$, against the expected cancer rates obtained from the country (18). During the 9 years of the study, 2,381 individuals developed cancer vs. the 2,187 expected [standardized incidence ratio $(\mathrm{SIR})=1.09,95 \% \mathrm{CI}$, 1.05-1.13]. Regarding BC, only 148 cases were registered in women and one in men (SIR=0.9, 95\% CI, 0.8-1.1; SIR=0.6, $95 \%$ CI, 0.0-3.2, respectively) (18). Even though their work had several strengths, there was not enough evidence to support the use of low-dose aspirin as a chemopreventive agent in cancer. Harris and colleagues reported similar findings in the same year for aspirin at a dose of $150 \mathrm{mg}$; they did not differ in regards to the observed risk (11).

In 2008, a Danish research group published another work in which participants were selected from the database of the Danish Diet, Cancer and Health Cohort (1993-1997) (19). A group of 28,695 Danish women between 50 and 64 years of age completed a questionnaire. In this study, other aspects related to risk were evaluated, such as frequency and duration of use, in addition to the presence of hormonal receptors. At the end of the survey (7.5 years), only 847 women were diagnosed with BC. Nevertheless, their work disclosed that the use of NSAIDs, including aspirin, did not diminish the risk of BC under any of the conditions mentioned before. On the contrary, an increase in breast cancer incidence was found in NSAID users compared to non-users $(\mathrm{RR}=1.27,95 \% \mathrm{CI}, 1.10-1.45)$. In the case of aspirin users, an increment of BC incidence was noted ( $\mathrm{RR}=1.38,95 \% \mathrm{CI}, 1.12-1.69)$ compared to NSAID users (not aspirin containing) ( $\mathrm{RR}=1.25,95 \% \mathrm{CI}, 1.04-1.49$ ).

Cook et al published similar results in 2005 (20). In this cohort study 39,876 healthy women participated and were randomly assigned to two groups: aspirin and aspirin placebo. Aspirin treatment consisted of a low concentration (100 mg), administered every other day for 10 years. For any cancer type (except non-melanoma skin cancer), the dose was not effective and no reduction in cancer risk was observed $(n=2,865$, $\mathrm{RR}=1.01,95 \% \mathrm{CI}, 0.94-1.08, \mathrm{P}=0.87)$; in particular for $\mathrm{BC}$, the values for a sample of 1,230 patients were $\mathrm{RR}=0.98(95 \% \mathrm{CI}$, $0.87-1.09, \mathrm{P}=0.68)$. Such a result could be related to the aspirin concentration used, since it has been observed that low doses of aspirin do not inhibit COX-2. In order to have a positive effect, aspirin must be ingested for longer periods. Likewise, the placebo group exhibited a similar behavior as the aspirin group.

In the same year, 2005, another research group found similar outcomes with almost twice as many patients $(77,413$ women) who were followed up for close to 10 years (21). Participants completed questionnaires from the Cancer Prevention Study II Nutrition Cohort (enrollments in 1992 or 1993; updates in 1997 and 1999). As in previous cohort study results, there was no direct association between current use of NSAIDs, with an average intake of 60 pills or more per month and $\mathrm{BC}$ incidence (NSAID users: $\mathrm{RR}=1.07,95 \% \mathrm{CI}, 0.96-1.21$ as compared to NSAID non-users; aspirin users: $\mathrm{RR}=1.01$, 95\% CI, 0.84-1.20 as compared to non-users). Moreover, for those patients that reported a consumption of $\geq 30$ pills per month for at least 5 years, the incidence of BC was not significant $(\mathrm{RR}=1.05,95 \% \mathrm{CI}, 0.88-1.26$ for total NSAIDs; $\mathrm{RR}=0.88$, 95\% CI, 0.69-1.12 for aspirin).

Two years later, in 2007, with information obtained from the Cancer Prevention Study II Nutrition Cohort in the US, aspirin was evaluated in regards to long-term daily use and the cancer incidence at a dose of $325 \mathrm{mg} /$ day in 10 different cancer types, including BC (22). Participants were diagnosed with cancer at the beginning of the enrollment in 1992-1993 and during follow-up until 2003. By 2003, 10,931 men and 7,196 women were diagnosed with a neoplasm. The incidence of cancer risk for men was associated with the use of aspirin for 5 years or longer. For women, on the contrary, the statistical difference was not significant, neither in general cancer nor in $\mathrm{BC}$ risk $(\mathrm{BC}: \mathrm{RR}=0.83,95 \% \mathrm{CI}=0.63-1.10)$. In this study, it was demonstrated that high concentrations of aspirin were not associated with cancer risk, while previous research reported low doses and short-term aspirin administration $(18,23)$.

In another cohort study carried out in 2007, which also evaluated aspirin and $\mathrm{BC}$ risk, the researchers focused on women smokers (22,507 patients) between 55 and 69 years of age (24). Notably, they found that the group of active smokers and aspirin consumers exhibited a reduction in cancer risk, differing with non-smoker or ex-smoker patients. This result could be attributed to the fact that smoking reduces the expression of COX-2 $(25,26)$. However, in a subsequent study, no relationship between $\mathrm{BC}$ risk and smoking status was noted (26). Finally, 
Bardia and colleagues (24) postulated that the use of aspirin could prevent the incidence of cancer by $4.7 \%$, and mortality by 3.5 and $7.6 \%$ in coronary diseases. Even though the results were promising, the research had various weaknesses such as the lack of dose data, duration of treatment, and the criteria used for population sample selection (the research was carried out in postmenopausal and Caucasian women).

Another prospective study evaluated 35,323 women, who were enrolled in the Vitamins and Lifestyle study (VITAL, 2008), where information regarding the use of NSAIDs, lifestyle and $\mathrm{BC}$ risk factors was required (27). Participants that used a low dose of aspirin 4 times/week or more, for an average of 10 years, showed a decrease in $\mathrm{BC}$ risk $(\mathrm{HR}=0.65$, 95\% CI, 0.43-0.97) vs. non-users. Interestingly, frequent use and a high dose of aspirin was associated with an increase in $\mathrm{BC}$ risk $(\mathrm{HR}=1.26,95 \% \mathrm{CI}, 0.96-1.65)$. This study found a protective effect of NSAIDs for long-term users of low doses or moderate frequency of high doses, contrary to frequent users of high dose that showed an increased risk.

Gill and colleagues (28) published a cohort study in 2007 integrating three relevant facts associated with $\mathrm{BC}$ risk in women: hormone receptor status of $\mathrm{BC}$, ethnicity and use of NSAIDs (aspirin, acetaminophen, ibuprofen, naproxen, and indomethacin). Mainly African-Americans, Caucasians, Japanese-Americans, Latinas and native Hawaiians, residents of Hawaii and California formed the multiethnic cohort even though other ethnicities were also documented. Data were collected between 1993 and 1996 by self-administered mail questionnaire; 98,920 women participated in this study. The results showed that aspirin was not associated with BC risk either for current or past users (HRR hazard rate ratio $=1.05$, 95\% CI, 0.88-1.25; HHR=1.04, 95\% CI, 0.84-1.27 for $\geq 6$ years of use; respectively, compared with non-users); while, NSAIDs (other than aspirin) presented a protective action against the risk of $\mathrm{BC}$ in current users $(\mathrm{HRR}=0.70,95 \% \mathrm{CI}, 0.51-0.95$, $\geq 6$ years of use). Regarding ethnicity and hormone receptor status, the protective effect of NSAIDs (long-term use of NSAIDs other than aspirin) was found in Caucasian and African-American women, and in women with at least one positive hormone receptor. In conclusion, the results suggested a protective effect of NSAIDs against BC risk associated with time, ethnic group and hormone receptor status. The use of NSAIDs for longer than 6 years decreased the risk by $30 \%$.

In summary, according to the aforementioned studies, there is not enough evidence yet to support aspirin as a possible drug to lower BC risk. On one hand, some of the studies suggest that aspirin could be a preventive treatment over long periods of ingestion (longer than 3 years). However, the main problem with long periods of aspirin consumption is its adverse reactions, such as peptic ulcers and gastrointestinal hemorrhage. These secondary effects are important to consider by physicians before prescribing to women with the possibility to develop BC.

Case-control studies. In 2000, a study was published in the UK with data collected from 1993 to 1995 (29). In this study 12,174 recruited patients were divided into two large groups: i) gastrointestinal cancer (esophagus, stomach, pancreas, colon and rectum) and ii) no gastrointestinal cancer (bladder, breast, lung and prostate); negative controls consisted of healthy patients (34,934 individuals) (29). The effect of aspirin and other NSAIDs was evaluated after 36 months of regular use. No important statistical difference was observed for either group $(\mathrm{OR}=0.98,95 \% \mathrm{CI}, 0.89-1.07$, for patients that received at least 7 prescriptions in the 13-36 months before cancer diagnosis). Similar results were obtained by a research group at Duke University, in North Carolina, US, who carried out a case-control study between 1996 and 2000. Their results showed an inverse relationship between invasive $\mathrm{BC}$ risk and the use of NSAIDs (OR=0.4, 95\% CI, 0.3-0.6) (30). Contrary to the other two reports, the findings of a study carried out in 2001 in Canada (3,133 patients and 3,062 controls), showed a benefit to women who had ingested NSAIDs (31). A $24 \%$ reduction in $\mathrm{BC}$ risk was observed $(\mathrm{OR}=0.76,95 \% \mathrm{CI}, 0.66-0.88)$, when NSAID intake was daily and for at least 2 months; for those patients with longer periods of intake (more than 8 years) they exhibited improvement $(\mathrm{OR}=0.68,95 \% \mathrm{CI}=0.54-0.86)$.

In the effort to determine an optimal dose administration of aspirin, García-Rodríguez et al studied 3,708 patients who were divided into three experimental groups according to aspirin concentration: 75,150 or $300 \mathrm{mg}$ (32). In this casecontrol study, the lower dose was more effective (the relative risk decreased $33 \%$ ) in comparison to the higher doses, where no significant differences were obtained (aspirin $\mathrm{RR}=0.77$; NSAIDs (non-aspirin) $\mathrm{RR}=1.00$; acetaminophen $\mathrm{R}=0.76$ ). Moreover, they reported that there was no correlation between time of intake and benefit (32).

The majority of the epidemiologic studies performed with aspirin are focused on dose-effect; few studies have consider time as a key factor in the chemopreventive effect of this medicine. However, Swede and colleagues reinvestigated this issue, testing aspirin with 1,478 patients diagnosed with BC and 3,383 free of disease. The authors found that time was an important variable in $\mathrm{BC}$ risk. Patients that consumed aspirin once a week for 1 year reported an RR of 0.84 ; and for those women consuming aspirin daily for 10 years or more the RR value was 0.74 (33).

A more specific study was performed evaluating genetic variation in the interleukin-6 (IL-6) gene, aspirin and BC risk in the southeast region of the US (34). Four experimental groups were included depending on their ethnic origin (nonHispanic Caucasian women, native Hispanic-American women with $\mathrm{BC}$, and the respective negative controls for each group). In the group of Hispanic-American women, factors including postmenopausal status, free of hormone use before the trial, and recent use of aspirin, significantly decreased the $\mathrm{BC}$ risk $(\mathrm{OR}=0.56,95 \% \mathrm{CI}, 0.33-0.96)$. The $\mathrm{BC}$ risk was not significant in the group of non-Hispanic Caucasian women. Furthermore, the genotype and the haplotype of the IL- 6 gene modified the association between aspirin and BC significantly. Women that were not exposed to hormones presented a major benefit $(\mathrm{P}=0.06$ for non-Hispanic Caucasian women, and 0.04 for native Hispanic-American women). According to their findings, IL-6 may interfere either in inflammation or estrogen pathways, due to its interactions with aspirin and the different associations of exposure to hormones of postmenopausal women. Furthermore, their data suggest that when estrogens are not present, the alleles associated with low IL- 6 production levels and inflammation have a protective function. In addition, estrogen itself can modify levels of IL-6; thus the effect 
can only be observed in the absence of estrogens. Therefore, it can be concluded that IL- 6 could amend the relationship among estrogen, aspirin and $\mathrm{BC}$ risk.

\section{Aspirin as an inhibitor of metastasis}

Aspirin has not only been studied as a chemopreventive drug, but also as an inhibitor of metastasis. It is known that patients with $\mathrm{BC}$ have a $50 \%$ likelihood to develop metastasis after treatment (chemotherapy, radiation and/or surgery). The maspin protein (mammary serpin) and its mRNA are highly produced in normal breast epithelial cells (35), whereas their expression levels diminish in the presence of BC (36). Maspin protein is a tumor-suppressor serine protease, which is expressed in several tissues including mammary epithelia, prostate, epidermis, lung, and in the stromal cells of the cornea $(35,36,61,62)$. This protein is of special interest as it is able to inhibit cellular invasion and metastasis and to act as a tumor suppressor $(37,60)$.

Girish and colleagues proposed that aspirin corrects the production levels of maspin in human breast cells in vitro and in patients, regulating maspin to normal levels through the stimulation of nitric oxide (NO) synthesis independent of the insulin receptor (37). An epidemiologic example of this previously mentioned concept, is a study carried out in India, where the effect of aspirin and the incidence of metastasis in BC patients was determined (38). In this work, 35 women participated, and the age range was from 41 to 64 years. All of the women were diagnosed with BC and had been previously treated (chemotherapy, radiation and/or surgery). The patients consumed a dose of aspirin of $75 \mathrm{mg} / 70 \mathrm{~kg}$ body weight daily for 3 years. During this period of time, plasmatic levels of NO and maspin were measured, and a monthly surveillance of metastasis was performed by an oncologist and occasionally by biopsy. The control group consisted of 35 healthy volunteers whose plasma maspin levels were measured. The results showed that maspin levels were higher after $24 \mathrm{~h}$ of aspirin administration; such levels were maintained during the 3 years of treatment (initially maspin levels were $0.95 \pm 0.04 \mathrm{nM}$ increasing to $4.63 \pm 0.05 \mathrm{nM}$ at the end of treatment). Six patients developed metastasis, and the rest of the patients were, apparently, free of metastasis after 3 years. Researchers suggest that daily intake of aspirin in patients with previously treated $\mathrm{BC}$ may reduce the incidence of metastasis independent of the disease stage.

Recently, a large study performed in the UK with 17,285 patients was carried out in order to elucidate the preventive effect of aspirin on distant metastasis comparing adenocarcinomas vs. other cancer types (39). Patients were divided into four groups according to the metastasis target: i) metastasis to distant tissues (secondary tumors, particularly to the liver, lung, bone, brain or other tissues distant to the primary tumor); ii) metastasis to any specific region; iii) local invasion; and iv) patients presenting rapid progression of disease and not enough clinical information recovered. After data analysis, the authors concluded that aspirin may help reduce the risk of distant metastasis in certain types of cancers from 30 to $40 \%$, and in $50 \%$ of metastatic adenocarcinoma, using a low concentration ( $\leq 5 \mathrm{mg}$ daily) and long delivery formulation. Additionally, it was observed that aspirin had a major impact on individuals with adenocarcinomas, particularly in those cases where curative surgery was performed (as in BC). The authors proposed that the anti-metastatic activity of aspirin is mediated by platelets, based on the knowledge that they participate in cancer development and metastasis (40), protecting tumoral cells during their travel through the bloodstream. Moreover, platelets activate a coagulation system allowing microthrombosis formation, thus facilitating the hosting of tumoral cells in target tissues (41). In addition, it is known that thrombocytosis is a common disease in many cancer types and it is used as a poor prognostic indicator (42).

Regarding aspirin and breast cancer metastasis, a research group at Brigham and Women's Hospital together with the Harvard Medical School, performed a prospective observation study in order to evaluate whether aspirin could decrease the risk of death from BC (43). The study consisted of 4,164 women (enrolled between 1976 and 2002; followed up until death or June 2006). According to their results, the use of aspirin reduced the risk of metastasis and $\mathrm{BC}$ death. The adjusted relative risks (stage of cancer, menopausal status, BMI, hormone receptor status) for distant recurrence were: for 1 day/week, RR=0.91 (95\% CI, 0.62-1.33); 2-5 days/week, $\mathrm{RR}=0.40$ (95\% CI, 0.24-0.65); and for 6-7 days/week, $\mathrm{RR}=0.57$ (95\% CI, 0.39-0.82).

Evidence to date regarding the use of aspirin as an inhibitor of metastasis in patients diagnosed with cancer, suggests that aspirin delays the invasion of cancer cells to other tissues and in some cases prevents metastasis formation. The information indicates that regular consumption of aspirin and long periods of administration are required for a positive result.

\section{Aspirin, mechanisms of action}

NSAIDs can be classified depending on their mechanisms of action on the COX enzyme: classical NSAIDs (including aspirin) and COX-2 inhibitors (celecoxib and rofecoxib are mainly used). The molecular mechanism by which aspirin and other classical NSAIDs are capable of inhibiting COX-1 and COX-2, is by competing with arachidonic acid for binding to the active site of cyclooxygenase; this is a rapid and an irreversible union, followed by the covalent acetylation of serine 530 in COX-1, hampering the oxidation of arachidonic acid (Fig. 1) (44). After the same modification, COX-2 can still convert arachidonic acid into 15R-hydroxyeicosatertraenoic acid (HETE), instead of PGG2 (45). On the other hand, it is believed that specific inhibitors of COX-2 bind to valine 523, whereas in COX-1 access to this binding site is blocked by the isoleucine residue at the same position (46). This difference explains the different degrees of inhibition towards COX-1 and COX-2 that aspirin possesses.

As known, there are two major isoforms of the COX enzyme, COX-1 that is expressed constitutively, and COX-2, which is induced locally as part of an inflammatory cascade and during early tumor development $(46,47)$. COX-1 performs positive homeostatic functions. It is antithrombotic when released to vascular endothelium and is cytoprotective when produced by the gastric mucous. Moreover, it provokes platelet aggregation and prevents inappropriate bleeding when it is thromboxane A2-dependent (48). On the other hand, COX-2, in addition to its action in tissular damage response, could be constitutively expressed in the brain, kidney, cells of the 
Table I. Comparative table of studies associating aspirin or NSAID use and the risk of breast cancer.

\begin{tabular}{|c|c|c|c|c|c|}
\hline Study & $\begin{array}{l}\text { No. of } \\
\text { patients }\end{array}$ & RR/OR/SIR & $95 \% \mathrm{CI}$ & Outcome & $\begin{array}{c}\text { Authors, year } \\
\text { of publication } \\
\text { (ref) }\end{array}$ \\
\hline Case-control & $\begin{array}{l}12,174 \text { patients } \\
34,934 \text { control }\end{array}$ & $\mathrm{RR}=0.98$ & $0.89-1.07$ & $\begin{array}{l}\text { Effect of NSAIDs on } 9 \text { different cancers } \\
\text { (gastrointestinal and not intestinal) } \\
\text { Reduction in gastric cancers, } \\
36 \text { months of use previous to diagnosis } \\
\text { of the disease }\end{array}$ & $\begin{array}{l}\text { Langman et al, } \\
2000(29)\end{array}$ \\
\hline Case-control & $\begin{array}{l}3,133 \text { patients } \\
3,062 \text { control }\end{array}$ & $\mathrm{OR}=0.76$ & $0.66-0.88$ & $\begin{array}{l}\mathrm{OR}=0.68(95 \% \mathrm{CI}, 0.54,0.86) \\
\text { for users of NSAIDs longer than } 8 \text { years }\end{array}$ & $\begin{array}{l}\text { Cotterchio et al, } \\
2001(31)\end{array}$ \\
\hline Cohort-study & $\begin{array}{l}27,616 \\
\text { postmenopausal } \\
\text { women }\end{array}$ & $\begin{array}{l}\mathrm{RR}=0.71 \\
\mathrm{RR}=1.01\end{array}$ & $\begin{array}{l}0.58-0.87 \\
0.83-1.25\end{array}$ & $\begin{array}{l}\text { Aspirin consumers at least } 6 \text { times/week } \\
\text { NSAID consumers at least } 6 \text { times/week }\end{array}$ & $\begin{array}{l}\text { Johnson et al, } \\
2002(10)\end{array}$ \\
\hline Cohort-study & $\begin{array}{l}29,470 \\
\text { participants } \\
\text { (both genders) } \\
\text { SIR calculated } \\
\text { for both genders }\end{array}$ & $\begin{array}{l}\text { SIR }=0.9 \\
\text { SIR }=0.1 \\
\text { SIR }=0.9\end{array}$ & $\begin{array}{l}0.7-1.1 \\
0.8-1.2 \\
0.8-1.1\end{array}$ & $\begin{array}{l}150 \mathrm{mg} \text { of aspirin during } 9 \text { years } \\
\text { Colon cancer } \\
\text { Rectal cancer } \\
\text { Breast cancer }\end{array}$ & $\begin{array}{r}\text { Friis et al, } \\
2003(18)\end{array}$ \\
\hline Cohort-study & $\begin{array}{l}80,741 \\
\text { postmenopausal } \\
\text { women } \\
1,392 \text { confirmed } \\
\text { cases of breast } \\
\text { cancer }\end{array}$ & $\begin{array}{l}\mathrm{RR}=0.79 \\
\mathrm{RR}=0.72 \\
\mathrm{RR}=0.51 \\
\mathrm{RR}=0.79\end{array}$ & $\begin{array}{l}0.60-1.04 \\
0.56-0.91 \\
0.28-0.96 \\
0.60-1.03\end{array}$ & $\begin{array}{l}\text { NSAID regular use } \\
\text { ( } 2 \text { or more tablets/week; } 5-9 \text { years) } \\
\text { NSAID regular use ( } 10 \text { or more years) } \\
\text { Ibuprofen (long-term use) } \\
\text { Aspirin (long-term use) }\end{array}$ & $\begin{array}{l}\text { Harris et al, } \\
2003 \text { (11) }\end{array}$ \\
\hline Cohort-study & $\begin{array}{l}734,899 \text { women } \\
\text { enrolled } \\
3,708 \text { patients } \\
\text { diagnosed with } \\
\text { breast cancer }\end{array}$ & $\begin{array}{l}\mathrm{OR}=0.77 \\
\mathrm{OR}=0.76\end{array}$ & $\begin{array}{l}0.62-0.95 \\
0.65-0.88\end{array}$ & $\begin{array}{l}\text { Daily doses of } 75 \mathrm{mg} \text { of aspirin } \\
\text { and } 2,000 \mathrm{mg} \text { of paracetamol } \\
\text { more effective dosages, } \\
\text { compared to non-users } \\
\text { Aspirin (1 year or longer) } \\
\text { Ibuprofen (1 year or longer) }\end{array}$ & $\begin{array}{l}\text { García- } \\
\text { Rodríguez } \\
\text { and } \\
\text { González, } \\
\text { Pérez, 2004 } \\
\text { (32) }\end{array}$ \\
\hline Case-control & $\begin{array}{l}1,442 \text { cases } \\
1,429 \text { control } \\
\text { users of aspirin, } \\
\text { ibuprofen and } \\
\text { acetaminophen }\end{array}$ & $\begin{array}{l}\mathrm{OR}=0.72 \\
\mathrm{OR}=0.74 \\
\mathrm{OR}=0.97\end{array}$ & $\begin{array}{l}0.58-0.90 \\
0.60-0.93 \\
0.67-1.40\end{array}$ & $\begin{array}{l}\text { Ever use of aspirin or other NSAIDs, } \\
\text { once/week, } 6 \text { months or longer, ever } \\
\text { vs. non-users } \\
\text { Frequent users ( }>7 \text { tablets/week) } \\
\text { Aspirin users with hormone } \\
\text { receptor-positive tumors } \\
\text { Aspirin users with hormone } \\
\text { receptor-negative tumors }\end{array}$ & $\begin{array}{l}\text { Terry et al, } \\
2004(16)\end{array}$ \\
\hline Cohort-study & $\begin{array}{l}22,834 \\
\text { individuals }\end{array}$ & $\begin{array}{l}\mathrm{RR}=1.07 \\
\mathrm{RR}=0.82 \\
\mathrm{RR}=0.90 \\
\mathrm{RR}=0.98\end{array}$ & $\begin{array}{l}0.84-1.35 \\
0.49-1.36 \\
0.73-1.13 \\
0.84-1.14\end{array}$ & $\begin{array}{l}\text { Cancer mortality in women (aspirin users) } \\
\text { Breast cancer mortality (aspirin users) } \\
\text { Cancer mortality in men (aspirin users) } \\
\text { Aspirin use and mortality both genders }\end{array}$ & $\begin{array}{l}\text { Ratnasinghe et al, } \\
2004 \\
(12)\end{array}$ \\
\hline Case-control & $\begin{array}{l}1,478 \\
\text { breast cancer } \\
\text { patients } \\
3,838 \text { control }\end{array}$ & $\mathrm{OR}=0.84$ & $0.64-0.97$ & Regular use (1 tablet/week) & $\begin{array}{l}\text { Swede } \text { et al, } \\
2005(33)\end{array}$ \\
\hline Cohort-study & $\begin{array}{l}19,934 \text { patients } \\
\text { aspirin } 100 \mathrm{mg} \\
19,942 \text { patients } \\
\text { aspirin placebo }\end{array}$ & $\begin{array}{l}\mathrm{RR}=1.01 \\
\mathrm{RR}=0.98\end{array}$ & $\begin{array}{l}0.94-1.08 \\
0.87-1.09\end{array}$ & $\begin{array}{l}\text { Total cancer } \\
\text { Breast cancer }(1,230 \text { cases }) \\
\text { No effect of aspirin was observed } \\
\text { in reduction of risk, except lung cancer } \\
(\mathrm{n}=205 \text { patients; } \\
\mathrm{RR}=0.78,95 \% \mathrm{CI}, 0.59-1.03)\end{array}$ & $\begin{array}{l}\text { Cook et al, } \\
2005(20)\end{array}$ \\
\hline
\end{tabular}


Table I. Continued.

\begin{tabular}{|c|c|c|c|c|c|}
\hline Study & $\begin{array}{l}\text { No. of } \\
\text { patients }\end{array}$ & RR/OR/SIR & $95 \% \mathrm{CI}$ & Outcome & $\begin{array}{l}\text { Authors, year } \\
\text { of publication } \\
\text { (ref) }\end{array}$ \\
\hline Case-control & $\begin{array}{l}7,006 \text { incidents } \\
\text { of breast cancer }\end{array}$ & $\mathrm{OR}=0.78$ & $0.63-0.97$ & $\begin{array}{l}\text { Regular use of NSAIDs } \\
\text { Regular use of aspirin OR=0.86 }\end{array}$ & $\begin{array}{l}\text { Zhang et al, } \\
2005 \text { (17) }\end{array}$ \\
\hline \multirow[t]{4}{*}{ Cohort-study } & 114,460 patients & $\mathrm{RR}=0.98$ & $0.86-1.13$ & $\begin{array}{l}\text { Breast cancer risk for daily vs. no regular } \\
\text { use of aspirin }\end{array}$ & $\begin{array}{l}\text { Marshall et al, } \\
2005 \text { (13) }\end{array}$ \\
\hline & $\begin{array}{l}\text { 2,391 diagnosed } \\
\text { with } \mathrm{BC}\end{array}$ & $\mathrm{RR}=1.09$ & $0.97-1.21$ & $\begin{array}{l}\text { Breast cancer risk for daily vs. no regular } \\
\text { use of NSADs }\end{array}$ & \\
\hline & & $\mathrm{RR}=0.80$ & $0.62-1.03$ & $\begin{array}{l}\text { Long term ( } \geq 5 \text { years) daily aspirin users } \\
\text { for ER/PR-positive BC }\end{array}$ & \\
\hline & & $\mathrm{RR}=1.81$ & $1.12-2.92$ & $\begin{array}{l}\text { Long term ( } \geq 5 \text { years) daily aspirin users } \\
\text { for ER/PR-negative BC }\end{array}$ & \\
\hline \multirow[t]{3}{*}{ Cohort-study } & $\begin{array}{l}77,413 \text { patients } \\
3,008 \text { cases of } \\
\text { breast cancer }\end{array}$ & & & $\begin{array}{l}\text { No incidence association was found with } \\
\text { the use of NSAIDs or aspirin in either } \\
\text { short- or long-time use ( } \geq 5 \text { years) }\end{array}$ & $\begin{array}{l}\text { Jacobs et al, } \\
2005(21)\end{array}$ \\
\hline & & $\mathrm{RR}^{\mathrm{a}}=1.05$ & $0.88-1.26$ & $\begin{array}{l}\text { Long-time regular use of NSAIDs compared } \\
\text { with no use ( } \geq 30 \text { pills/month; } \geq 5 \text { years) }\end{array}$ & \\
\hline & & $\mathrm{RR}^{\mathrm{a}}=0.88$ & $0.69-1.12$ & $\begin{array}{l}\text { Long-time regular use of aspirin compared } \\
\text { with nonuse ( } \geq 30 \text { pills/month; } \geq 5 \text { years) }\end{array}$ & \\
\hline \multirow[t]{3}{*}{ Cohort-study } & $\begin{array}{l}22,507 \\
\text { postmenopausal }\end{array}$ & $\mathrm{RR}=0.84$ & $0.77-0.90$ & $\begin{array}{l}\text { Aspirin users compared with non-user } \\
\text { cancer incidence }\end{array}$ & $\begin{array}{l}\text { Bardia et al, } \\
2007(24)\end{array}$ \\
\hline & women & $\mathrm{RR}=0.87$ & $0.76-0.99$ & $\begin{array}{l}\text { Aspirin users compared with non-user } \\
\text { cancer mortality }\end{array}$ & \\
\hline & $\begin{array}{l}3,487 \text { cases } \\
\text { of cancer } \\
3,581 \text { deaths }\end{array}$ & & & & \\
\hline \multirow[t]{5}{*}{ Cohort-study } & 98,920 women & & & $\begin{array}{l}\text { Multi-ethnic cohort study (African-American, } \\
\text { Caucasian, Japanese-American, Latina } \\
\text { and native Hawaiian women) }\end{array}$ & $\begin{array}{l}\text { Gill et al, } \\
2007 \text { (28) }\end{array}$ \\
\hline & & $\mathrm{HRR}=1.05$ & $0.88-1.25$ & $\begin{array}{l}\text { Current users of aspirin } \\
\text { breast cancer risk } \geq 6 \text { years of use }\end{array}$ & \\
\hline & & $\mathrm{HRR}=1.04$ & $0.84-1.27$ & $\begin{array}{l}\text { Past users of aspirin } \\
\text { breast cancer risk for } \geq 6 \text { years of use } \\
\text { compared with non-users }\end{array}$ & \\
\hline & & $\mathrm{HRR}=0.70$ & $0.51-0.95$ & $\begin{array}{l}\text { Current users of other NSAIDs } \\
\text { was protective for } \geq 6 \text { years of use }\end{array}$ & \\
\hline & & $\mathrm{HRR}=0.90$ & $0.62-1.30$ & $\begin{array}{l}\text { Past users of other NSAIDs } \\
\text { was not protective for } \geq 6 \text { years of use }\end{array}$ & \\
\hline \multirow[t]{5}{*}{ Cohort-study } & 69,810 men & $\mathrm{RR}^{\mathrm{a}}=0.84$ & $0.76-0.93$ & $\begin{array}{l}\text { Overall cancer incidence in men } \\
(\geq 5 \text { years of use })\end{array}$ & $\begin{array}{l}\text { Jacobs et al, } \\
2007(22)\end{array}$ \\
\hline & $\begin{array}{l}76,303 \text { women } \\
\text { at enrollment }\end{array}$ & $\mathrm{RR}^{\mathrm{a}}=0.86$ & $0.73-1.03$ & $\begin{array}{l}\text { Overall cancer incidence in women } \\
(\geq 5 \text { years of use })\end{array}$ & \\
\hline & 10,931 men and & $\mathrm{RR}^{\mathrm{a}}=0.68$ & $0.52-0.90$ & $\begin{array}{l}\text { Colorectal cancer (both genders); } \\
\text { long-term daily aspirin use, lower incidence }\end{array}$ & \\
\hline & $\begin{array}{l}\text { 7,196 women } \\
\text { developed }\end{array}$ & $\mathrm{RR}^{\mathrm{a}}=0.81$ & $0.70-0.94$ & $\begin{array}{l}\text { Prostate cancer; long-term daily aspirin use } \\
\text { in men }\end{array}$ & \\
\hline & cancer & $\mathrm{RR}^{\mathrm{a}}=0.83$ & $0.63-1.10$ & $\begin{array}{l}\text { Breast cancer; long-term daily aspirin use } \\
\text { in women } \\
\text { Aspirin } 325 \mathrm{mg} / \text { day }\end{array}$ & \\
\hline
\end{tabular}


Table I. Continued.

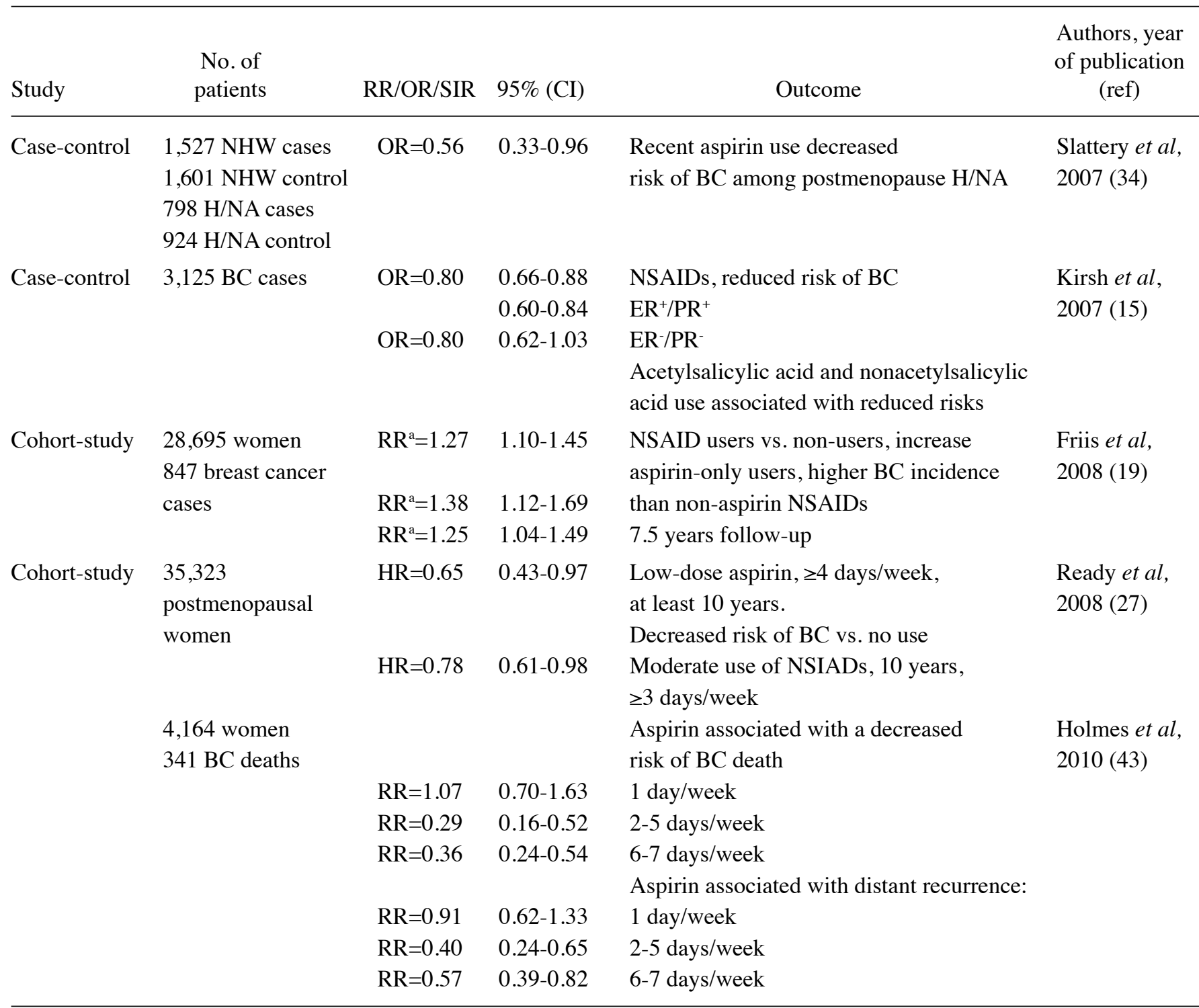

NHW, non-Hispanic Caucasian women; H/NA, native Hispanic women; RR, relative risk; OR, odds ratio; SIR, standardized incidence ratio; ${ }^{a} \mathrm{RR}$, rate ratio; HRR, hazard rate ratio; CI, confidence interval; NSAIDs, non-steroidal anti-inflammatory drugs; PR, progesterone receptor; ER, estrogen receptor.

pancreatic islet, ovary, gestational uterus and intestine $(49,50)$. COX-2 is present in several cancer cell lines and is implicated in carcinogenesis, tumor growth, apoptosis and angiogenesis $(51,52)$. As these isoforms are encoded in independent genes with different chromosomal localizations, their expression and regulation patterns differ. More recently, a third isoform, named COX-3, was identified as a COX-1 splice variant that may play an important role in fever and pain processes (53).

These enzymes are responsible for catalyzing the conversion of arachidonic acid to prostaglandin endoperoxide (prostaglandin $\mathrm{H} 2$ ) and thromboxanes; both COX-1 and COX-2 participate in maintaining physiological regulation in the stomach, platelets, kidneys and intestine (46). The principal side effects of aspirin and NSAIDs such as gastropathy, renal insufficiency and impaired vascular homeostasis among others, are due to a reduction in the appropriate prostaglandins in these organs (46). Prostaglandins are short-lived compounds acting as local mediators of continuous importance in normal cellular reactions, but they appear to be increased in several pathological conditions, particularly inflammation (46), and it has also been shown that the level of prostaglandins in various tumors is greater than that of normal tissues (54).

Reports from the past 15 years, have shown that COX-1 is localized in stromal cells adjacent to the tumor but not in tumor cells. In contrast, high levels of COX-2 are localized primarily in tumor cells but also appear in stromal cells (54). Such is the case of certain malignant human breast tumors that produce more prostaglandin-like material than do benign tumors or normal breast tissues (54).

Additional experimental data suggest that COX-2 can be induced by a mutation of the tumor-suppressor gene APC, subsequently increasing the expression of the nuclear transcription factor PPAR- $\delta$ (55). Induction of COX-2 expression 


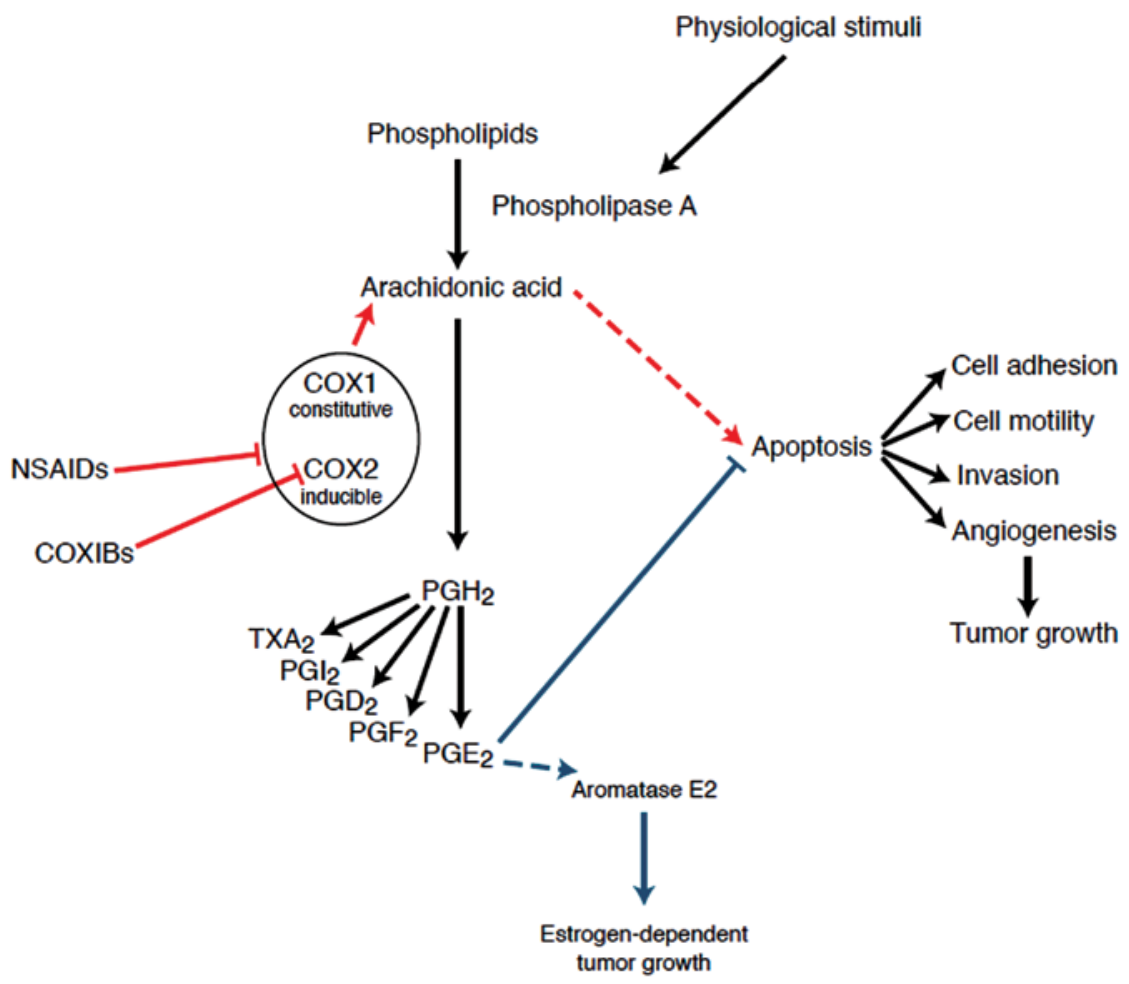

Figure 1. The mechanisms of action of aspirin. Prostaglandin synthesis via arachidonic acid and the possible effects of cyclooxygenase inhibitors as chemopreventive agents of breast cancer by the intracellular accumulation of arachidonic acid, which directly promotes apoptosis and attenuation of positive feedback for proliferation and survival. COX, cyclooxygenase; PG, prostaglandin; TXA2, thromboxane A2; NSADs, non-steroidal anti-inflammatory drugs; COXIBs, COX-2 selective inhibitors.

in tumors can also occur by lipopolysaccharide through the mitogen-activated protein kinase (MAPK) and protein kinase $\mathrm{C}$-(PKC) pathways (56). Ceramide-stimulated activation of MAPK can also activate c-Jun N-terminal kinase (JNK), which in turn can lead to increased COX-2 gene expression in human mammary epithelial cells (57). In breast tissue, induction of COX-2 expression can trigger prostaglandin production, which indirectly stimulates cellular proliferation increasing the local biosynthesis of estrogen and increasing the expression of the aromatase gene $(8,58)$. In humans, high levels of prostaglandins have been related with metastatic potential and reduced survival of patients (22). Such a process could be reversible when COX-2 is inhibited using NSAIDs with the purpose of reducing prostaglandin synthesis. For those women who present with tumors with positive hormone receptors, the use of aspirin could contribute to the suppression of aromatase activity, reducing the intra-mammary prostaglandin production, and thus, estrogen production (59). In particular, it has been shown that $\mathrm{E} 2$ prostaglandin $\left(\mathrm{PGE}_{2}\right)$ stimulates the transcription of aromatase, increasing the estrogen levels and, moreover, contributing to the progression of estrogen-dependent BC (60).

The induction and overexpression of COX-2 and its main product $\mathrm{PGE}_{2}$ in human mammary tissue, have also been associated with aromatase-catalyzed estrogen biosynthesis (61). In addition, some epidemiologic studies have reported that hormone-receptor-positive breast tumors are more responsive to aspirin (62). The ability of aspirin and other NSAIDs to protect against breast cancer might vary according to hormone receptor status. For instance, in 2004, a case-control study, reported a reduction in risk only in women with hormone receptor-positive tumors, but not in women with hormone receptor-negative tumors (9). Moreover, COX-2 is related to the activation of carcinogens, mutagenesis, angiogenesis, inhibition of apoptosis and metastasis $(53,63,64)$. In contrast, COX-2 inhibition may reverse these processes; aspirin and salicylates may also suppress NF- $\kappa$ B-related survival signaling by inhibiting IKK $\alpha$ activation, leading to apoptosis (45).

Molecular studies have also revealed a strong correlation between overexpression of COX-2 and other oncogenes, such as HER-2/Neu, in malignant breast tumors $(65,66)$. A linkage between the expression of COX-2 and MDR1/Pgp 170 was shown by immunohistochemical analyses in human breast tumor specimens, and it is well known that overexpression of P-glycoprotein contributes to primary chemotherapy resistance $(66,67)$.

Regarding the possible anti-metastatic effect of aspirin, it was demonstrated that the daily ingestion of aspirin in patients previously treated with standard therapies indeed reduces metastasis, assigning this effect to the maspin protein (38). Maspin is a serine protease inhibitor of $42 \mathrm{kDa}$ synthesized abundantly in normal mammary epithelial cells, and it has been shown that the expression of this protein is reduced in patients with breast cancer. Thus, the lack of expression of maspin in breast cancer has been suggested to indicate the presence of an aggressive and metastatic tumor (36). Studies have revealed that ingestion of aspirin increases the levels of serum nitric oxide (NO) and maspin, both of which inhibited the growth of breast cancer cells in vitro, as well as invasion and metastatic processes in an animal model $(9,38)$. This finding suggests 
that aspirin participates in the restoration of maspin synthesis at any stage of the disease, and also that maspin presents beneficial effects at any stage of tumoral progression. It has been observed that maspin is reduced in $\mathrm{BC}$, or even absent in invasive cancer; hence, there is a correlation between the protein synthesis and its reduction according to cancer type and stage (67). There is also evidence of maspin as an inhibitor of angiogenesis (68).

On the other hand, in 2008, Burnett and collaborators investigated the relationship between inflammation and angiogenesis and how it is regulated by aspirin. They proposed that aspirin alters macrophage regulation by inducing expression of IL-10 in MCF-7 cells, and suggested aspirin as a therapeutic strategy for modification of tumor-associated macrophages (TAMs), which can initiate both angiogenesis and invasion (69).

Finally, regarding the mechanisms of aspirin as an antitumor drug (70), Spitz et al discuss the use of acetylsalicylic acid (ASA) and salicylic acid (SA) in tumor cell viability and glucose metabolism. Both drugs modulate an important glycolysis-regulatory intracellular enzyme (6-phosphofructo1-kinase, PFK) in a dose-dependent manner, and the inhibition occurs due to the modulation of the enzyme quaternary structure. The authors demonstrated that ASA, as well as its precursor SA, decreased the viability of the human breast tumor cell line MCF-7, diminishing its glucose consumption and PFK activity.

\section{Conclusions}

One of the most significant discoveries along the quest for novel cancer treatments and preventive therapies has been the COX-2 inhibitors. These drugs have been demonstrated to interfere directly with the carcinogenesis process, restoring apoptosis. The most representative medicine of the last 100 years is probably aspirin, a drug that is still currently under investigation. The COX-2 gene is overexpressed in breast cancer; furthermore, the presence of the COX-2 enzyme in tumoral tissue is directly proportional to the density of cancer cells. Moreover, some studies have revealed that high levels of prostaglandins are linked to unfavorable patient characteristics, such as the risk to develop metastasis and the reduction in survival rate, being good indicators for the correct diagnosis of disease stage.

In respect to the epidemiologic studies reported here, it is of great importance to homologate criteria in this type of research, for example, the time of administration of the drug, in order to truly assess the chemopreventive and anti-metastatic effect of aspirin. This issue should be considered because of the great variability existing in studies.

Evidence of the chemopreventive effect of aspirin cited in this review, suggests that it is likely to lower $\mathrm{BC}$ risk when administrated at doses greater than $100 \mathrm{mg}$ /day for 3 or more years. Such information suggests that aspirin may start being favorable after a long period of regular use. However, this dosage poses adverse reactions, such as, an increase in gastric ulcer risk and gastrointestinal bleeding. Cancer is a multifactorial disease, and its behavior is constantly being investigated toward a greater understand and, at the same time, to propose less aggressive and more effective therapies or, when possible, chemopreventive alternatives. Aspirin could yield beneficial results for a specific group of risk patients, but who should be monitored carefully if there are any contraindications to the medicine. In conclusion, aspirin is a suitable alternative in this non-stop search for cancer prevention and treatment.

\section{Acknowledgements}

We express our gratitude to Dr Alberto Huberman from INCMNSZ for improving this manuscript. Elizabeth Camacho Zavala thanks Posgrado en Ciencias Biológicas, UNAM and to CONACyT for scholarship support (no. 412740).

\section{References}

1. Ferlay J, Shin HR, Bray F, Forman D, Mathers C and Parkin DM: Estimates of worldwide burden of cancer in 2008: GLOBOCAN 2008. Int J Cancer 127: 2893-2917, 2010.

2. Chávarri-Guerra Y, Villarreal-Garza C, Liedke PE, et al: Breast cancer in Mexico: a growing challenge to health and the health system. Lancet Oncol 13: e335-e343, 2012.

3. Rodríguez-Cuevas SA and Capurso-García M: Epidemiology of breast cancer. Ginecol Obstet Mex 74: 585-593, 2006 (In Spanish).

4. Zentella-Dehesa A, Frías S, Galicia-Vázquez G, et al: Cáncer de glándula mamaria y metástasis: un creciente problema de salud pública en México. In: Mensaje Bioquímico (Oria Hernández J, Rendón Huerta E, Reyes Vivas H, Romero Álvarez I, Velázquez López I (eds.). Mexico, UNAM Vol. XXXI, pp 172-195, 2007.

5. Spallarossa P, Altieri P, Aloi C, et al: Doxorubicin induces senescence or apoptosis in rat neonatal cardiomyocytes by regulating the expression levels of the telomere binding factors 1 and 2. Am J Physiol Heart Circ Physiol 297: H2169-H2181, 2009.

6. Elliott P: Pathogenesis of cardiotoxicity induced by anthracyclines. Semin Oncol 33: S2-S7, 2006.

7. Rice J: Metastasis: The rude awakening. Nature 485: S55-S57, 2012.

8. Khuder SA and Mutgi AB: Breast cancer and NSAID use: a meta-analysis. Br J Cancer 84: 1188-1192, 2001.

9. Agrawal A and Fentiman IS: NSAIDs and breast cancer: a possible prevention and treatment strategy. Int J Clin Pract 62: 444-449, 2008.

10. Johnson TW, Anderson KE, Lazovich D and Folsom AR: Association of aspirin and nonsteroidal anti-inflammatory drugs use with breast cancer. Cancer Epidemiol Biomarkers Prev 11: 1586-1592, 2002.

11. Harris RE, Chlebowski RT, Jackson RD, et al: Breast cancer and nonsteroidal anti-inflammatory drugs: prospective results from the Women's Health Initiative. Cancer Res 63: 6096-6101, 2003.

12. Ratnasinghe LD, Graubard BI, Kahle L, Tangrea JA, Taylor PR and Hawk E: Aspirin use and mortality from cancer in a prospective cohort study. Anticancer Res 24: 3177-3184, 2004.

13. Marshall SF, Bernstein L, Anton-Culver H, et al: Nonsteroidal anti-inflammatory drugs use and breast cancer risk by stage and hormone receptor status. J Natl Cancer Inst 97: 805-812, 2005.

14. Egan KM, Stampfer MJ, Giovannucci E, Rosner BA and Colditz GA: Prospective study of regular aspirin use and the risk of breast cancer. J Natl Cancer Inst 88: 988-993, 1996.

15. Kirsh VA, Kreiger N, Cotterchio M, Sloan M and Theis B: Nonsteroidal anti-inflammatory drug use and breast cancer risk: subgroup findings. Am J Epidemiol 166: 709-716, 2007.

16. Terry MB, Gammon MD, Zhang FF, et al: Association of frequency and duration of aspirin use and hormone receptor status with breast cancer risk. JAMA 291: 2433-2440, 2004.

17. Zhang Y, Coogan PF, Palmer JR, Strom BL and Rosenberg L: Use of nonsteroidal anti-inflammatory drugs and risk of breast cancer: the case-control surveillance study revisited. Am J Epidemiol 162: 165-170, 2005.

18. Friis S, Sørensen HT, McLaughlin JK, Johnsen SP, Blot WJ and Olsen JH: A population-based cohort study of the risk of colorectal and other cancers among users of low-dose aspirin. $\mathrm{Br}$ J Cancer 88: 684-688, 2003.

19. Friis S, Thomassen L, Sørensen HT, et al: Nonsteroidal antiinflammatory drug use and breast cancer risk: a Danish cohort study. Eur J Cancer Prev 17: 88-96, 2008.

20. Cook NR, Lee IM, Gaziano JM, et al: Low-dose aspirin in the primary prevention of cancer. The Women's Health Study: a randomized controlled trial. JAMA 294: 47-55, 2005. 
21. Jacobs EJ, Thun MJ,Connell CJ, et al: Aspirin and other nonsteroidal anti-inflammatory drugs and breast cancer incidence in a large U.S cohort. Cancer Epidem Biomarkers Prev 14: 261-264, 2005.

22. Jacobs EJ, Thun MJ, Bain EB, Rodriguez C, Henley SJ and Calle EE: A large cohort study of long-term daily use of adult strength aspirin and cancer incidence. J Nat Cancer Inst 99: 608-615, 2007

23. Schreinemachers DM and Everson RB: Aspirin use and lung, colon, and breast cancer incidence in a prospective study. Epidemiology 5: 138-146, 1994.

24. Bardia A, Ebbert JO, Vierkant RB, et al: Association of aspirin and non-aspirin non-steroidal anti-inflammatory drugs with cancer incidence and mortality. J Natl Cancer Inst 99: 881-889, 2007.

25. Badawi AF, Habib SL, Mohammed MA, Abadi AA and Michael MS: Influence of cigarette smoking on prostaglandin synthesis and cyclooxygenase-2 gene expression in human urinary bladder cancer. Cancer Invest 20: 651-656, 2002.

26. Martey CA, Pollock SJ, Turner CK, et al: Cigarette smoke induces cyclooxygenase-2 and microsomal prostaglandin E2 synthase in human lung fibroblast: implications for lung inflammation and cancer. Am J Physiol Lung Cell Mol Physiol 287: L981-L991, 2004.

27. Ready A, Velicer CM, McTiernan A and White E: NSAID use and breast cancer risk in the VITAL cohort. Breast Cancer Res Treat 109: 533-543, 2008

28. Gill JK, Maskarinec G, Wilkens LR, Pike MC, Henderson BE and Kolonel LN: Nonsteroidal anti-inflammatory drugs and breast cancer risk: the multiethnic cohort. Am J Epidemol 166: $1150-1158,2007$

29. Langman MJS, Cheng KK, Gilman EA and Lancashire RJ: Effect of anti-inflammatory drugs overall risk of common cancer: case-control study in general practice research database. BMJ 320: 1642-1646, 2000.

30. Moorman PG, Grubber JM, Millikan RC and Newman B Association between nonsteroidal anti-inflammatory drugs (NSAIDs) and invasive breast cancer and carcinoma in situ of the breast. Cancer Causes Control 14: 915-922, 2003.

31. Cotterchio M, Kreiger N, Sloan M and Steingart A: Nonsteroidal anti-inflammatory drug used and breast cancer risk. Cancer Epidemiol Biormarkers Prev 10: 1213-1217, 2001.

32. García Rodríguez LA and González Pérez A: Risk of breast cancer among users of aspirin and other anti-inflammatory drugs. Br J Cancer 91: 525-529, 2004.

33. Swede H, Mirand AL, Menezes RJ and Moysich KB: Association of regular aspirin use and breast cancer risk. Oncology 68: 40-47, 2005.

34. Slattery ML, Curtin K, Baumgartner R, et al: IL6, aspirin, nonsteroidal anti-inflammatory drugs, and breast cancer risk in women living in the southwestern United States. Cancer Epidemiol Biomarkers Prev 16: 747-755, 2007.

35. Hojo T, Akiyama Y, Nagasaki K, et al: Association of maspin expression with the malignancy grade and tumor vascularization in breast cancer tissues. Cancer Lett 171: 103-110, 2001.

36. Maass N, Hojo T, Rosel F, Ikeda T, Jonat W and Nagasaki K: Down regulation of the tumor suppressor gene maspin in breast carcinoma is associated with a higher risk of distant metastasis. Clin Biochem 34: 303-307, 2001

37. Girish GV, Sinha N, Chakraborty K, Bhattacharya G, Kahn NN and Sinha AK: Restoration by aspirin of impaired plasma maspin level in human breast cancer. Acta Oncol 45: 184-187, 2006.

38. Bhattacharyya M, Girish GV, Ghosh R, Chakraborty S and Sinha AK: Acetylsalicylic acid (aspirin) improves synthesis of maspin and lowers incidence of metastasis in breast cancer patients. Cancer Sci 101: 2105-2109, 2010

39. Rothwell PM, Wilson M, Price JF, Belch JF, Meade TW and Mehta Z: Effect of daily aspirin on risk of cancer metastasis: a study of incident cancers during randomised controlled trials. Lancet 379: 1592-1601, 2012.

40. Bambace NM and Holmes CE: The platelet contribution to cancer progression. J Thromb Haemostat 9: 237-249, 2011.

41. Joyce JA and Pollard JW: Microenvironmental regulation of metastasis. Nature Rev Cancer 9: 239-252, 2009.

42. Gay LJ and Felding-Habermann B: Contribution of platelets to tumour metastasis. Nature Rev Cancer 11: 123-134. 2011.

43. Holmes MD, Chen WY, Li L, Hetzmark E, Spiegelman D and Hankinson SE: Aspirin intake and survival after breast cancer. J Clin Oncol 28: 1467-1472, 2010.

44. Smith WL, DeWitt DL and Garavito RM: Cyclooxygenases: structural, cellular, and molecular biology. Annu Rev Biochem 69: 145-182, 2000.
45. Zha S, Yegnasubramanian V, Nelson WG, Isaacs WB and De Marzo AM: Cyclooxygenases in cancer: progress and perspective. Cancer Lett 215: 1-20, 2004.

46. Giercksky KE: COX-2 inhibition and prevention of cancer. Best Pract Res Clin Gastroenterol 15: 821-833, 2001.

47. Ulrich CM, Bigler J and Potter JD: Non-steroidal antiinflammatory drugs for cancer prevention: promise, perils and pharmacogenetics. Nature Review Cancer 6: 130-140, 2006.

48. Moran EM: Epidemiological and clinical aspects of nonsteroidal anti-inflammatory drugs and cancer risk. J Environ Pathol Toxicol Oncol 21: 193-202, 2002.

49. Vane JR and Botting RM: Mechanism of action of aspirin-like drugs. Semin Arthritis Rheum 26: 2-10, 1997.

50. Buttar NS and Wang KK: The "aspirin" of the new millenium: cyclooxigenase-2 inhibitors. Mayo Clin Proc 75: 1027-1038, 2000.

51. Elwood PC, Gallagher AM, Duthie GG, Mur LA and Morgan G: Aspirin, salicylates, and cancer. Lancet 373: 1301-1309, 2009.

52. Langley RE, Burdett S, Tierney JF, Cafferty F, Parmar MK and Venning G: Aspirin and cancer: has aspirin been overlooked as an adjuvant therapy? Br J Cancer 105: 1107-1113, 2011.

53. Meric JB, Rottey S, Olaussen K, Soria JC, Khayat D, Rixe O and Spano JP: Cyclooygenase-2 as a target for anticancer drug development. Crit Rev Oncol Hematol 59: 51-64, 2006.

54. Hwang D, Scollard D, Byrne J and Levine E: Expression of cyclooxygenase-1 and cyclooxygenase- 2 in human breast cancer. J Natl Cancer Inst 90: 455-460, 1998.

55. He TC, Chan TA, Volgestein B and Kinzlet KW: PPAR delta is an APC-regulated target of nonsteroidal anti-inflammatory drugs. Cell 99: 335-345, 1999.

56. Davies G, Martin LA, Sacks N and Dowsett M: Cyclooxygenase-2 (COX-2), aromatase and breast cancer: a possible role for COX-2 inhibitors in breast cancer chemoprevention. Ann Oncol 13: 669-678, 2002

57. Subbaramaiah K, Chung WJ and Dannenberg AJ: Ceramide regulates the transcription of cyclooxygenase-2. Evidence for involvement of extracellular signal-regulated kinase/c-Jun $\mathrm{N}$-terminal kinase and p38 mitogen-activated protein kinase pathways. J Biol Chem 273: 32943-32949, 1998.

58. Brueggemeier RW, Quinn AL, Parrett ML, Joarder FS, Harris RE and Robertson FM: Correlation of aromatase and cyclooxygenase gene expression in human breast cancer specimens. Cancer Lett 140: 27-35, 1999.

59. Goss PE, Ingle JN, Martino S, et al: A randomized trial of letrozole in postmenopausal women after five years of tamoxifen therapy for early breast cancer. N Engl J Med 349: 1793-1802, 2003.

60. Mazhar E, Ang R and Waxman J: COX inhibitors and breast cancer. Br J Cancer 94: 346-350, 2006.

61. Bosetti C, Gallus S and La Vecchia C: Aspirin and cancer risk: an updated quantitative review to 2005. Cancer Causes Control 17: 871-888, 2006.

62. Crew KD and Neugut AI: Aspirin and NSAIDs: effects in breast and ovarian cancers. Curr Opin Obstet Gynecol 18: 71-75, 2006.

63. Fosslien E: Molecular pathology of cyclooxygenase-2 in neoplasia: Ann Clin Lab Sci 30: 3-21, 2000.

64. Bosetti C, Gallus S and La Vecchia C: Aspirin and cancer risk: an update to 2001. Eur J Cancer Prev 11: 535-542, 2002.

65. Howe LR, Subbaramaiah K, Brown AMC and Dannenberg AJ: Cyclooxygenase-2: a target for the prevention and treatment of breast cancer. Endocr Relat Cancer 8: 97-114, 2001.

66. Ratnasinghe D, Daschner PJ, Anver MR, et al: Cyclooxygenase-2 P-glycoprotein-170 and drug resistance; is chemoprevention against multidrug resistance possible? Anticancer Res 21: 2141-2147, 2001.

67. Streuli CH: Maspin is a tumour suppressor that inhibits breast cancer tumour metastasis in vivo. Breast Cancer Res 4: 137-140, 2002.

68. Solomon LA, Munkarah AR, Schimp VL, et al: Maspin expression and localization impact on angiogenesis and prognosis in ovarian cancer. Gynecol Oncol 101: 385-389, 2006.

69. Burnett GT, Weathersby DC, Taylor TE and Bremner TA: Regulation of inflammation and angiogenesis-related gene expression in breast cancer cells and co-cultured macrophages. Anticancer Res 28: 2093-2099, 2008.

70. Spitz GA, Furtado CM, Sola-Penna $M$ and Zancan P: Acetylsalicylic acid and salicylic acid decrease tumor cell viability and glucose metabolism modulating 6-phosphofructo1-kinase structure and activity. Biochem Pharmacol 77: 46-53, 2009. 